nests from power poles to substitute sites. Canadian Field-Naturalist 97:315319.

2. Ewins, P.J. 1996. The use of artificial nest sites by an increasing population of Ospreys in the Canadian Great Lakes Basin. Pp. 109-123 In: D.M. Bird, D.E .Varland, and J.J. Negro (eds.). Raptors in Human Landscapes. San Diego: Academic Press.

3. Henny, C.H., and J.L. Kaiser. 1996. Osprey population increase along the
Willamette River, Oregon, and the role of utility structures, 1976-93. Pp. 97-108 In: D.M. Bird, D.E .Varland, and J.J. Negro (eds). Raptors in Human Landscapes. San Diego: Academic Press.

4. Pollock, L. 1999. Osprey rescues at Preeceville. Blue Jay 57:143-145.

5. Poole, A. 1989. Ospreys: A Natural and Unnatural History. Cambridge, UK: Cambridge University Press.

\title{
NOTES ON THE STATUS AND DISTRIBUTION OF THE LONG-BILLED CURLEW IN THE ROSETOWN- BIGGAR DISTRICT, SK
}

WAYNE E. RENAUD, 9 Oakwood Ave. N. Mississauga, ON L5G 3L6 and GUY J. WAPPLE, 322 Gillam Crescent, Saskatoon, SK S7N 3R9

\section{Introduction}

The status and distribution of the Long-billed Curlew in the RosetownBiggar area was fully documented up to 1975. ${ }^{2}$ Thereafter to 2001, additional records have been collected by Wayne Renaud, and Guy and Robert Wapple from the greater Rosetown-Biggar area. From 1996 to 1999 especially, intensive field work in the newly-extended Rosetown-Biggar area was undertaken for revision of The Birds of RosetownBiggar District, Saskatchewan. This paper updates the status and distribution of the Long-billed Curlew for the 1975 study area, and further clarifies the species' status west and north of the original study area. Locations of sightings are shown on Figure 1.

\section{Breeding Season Status}

Areas north of the original study area

The Struan area, $30 \mathrm{~km}$ north of the original study area boundary, is of particular interest because it appears to be the most northerly location for breeding records of Long-billed Curlew in the new area. Also there are historical records for this area by two farmernaturalists, Ernest and William Jasper, whose parents settled in the Struan area in early 1900s. They began keeping records in 1930s and found Long-billed Curlews to be common breeders throughout the 1930 s and $1940 \mathrm{~s}^{2}$. They noted that curlews had declined drastically by the mid-1970s when William Jasper left the area (William Jasper fide Robert Wapple). We are 
Figure 1. Rosetown-Biggar District. Cross hatching indicates areas where Long-billed Curlews occur regularly in summer and presumably breed each year

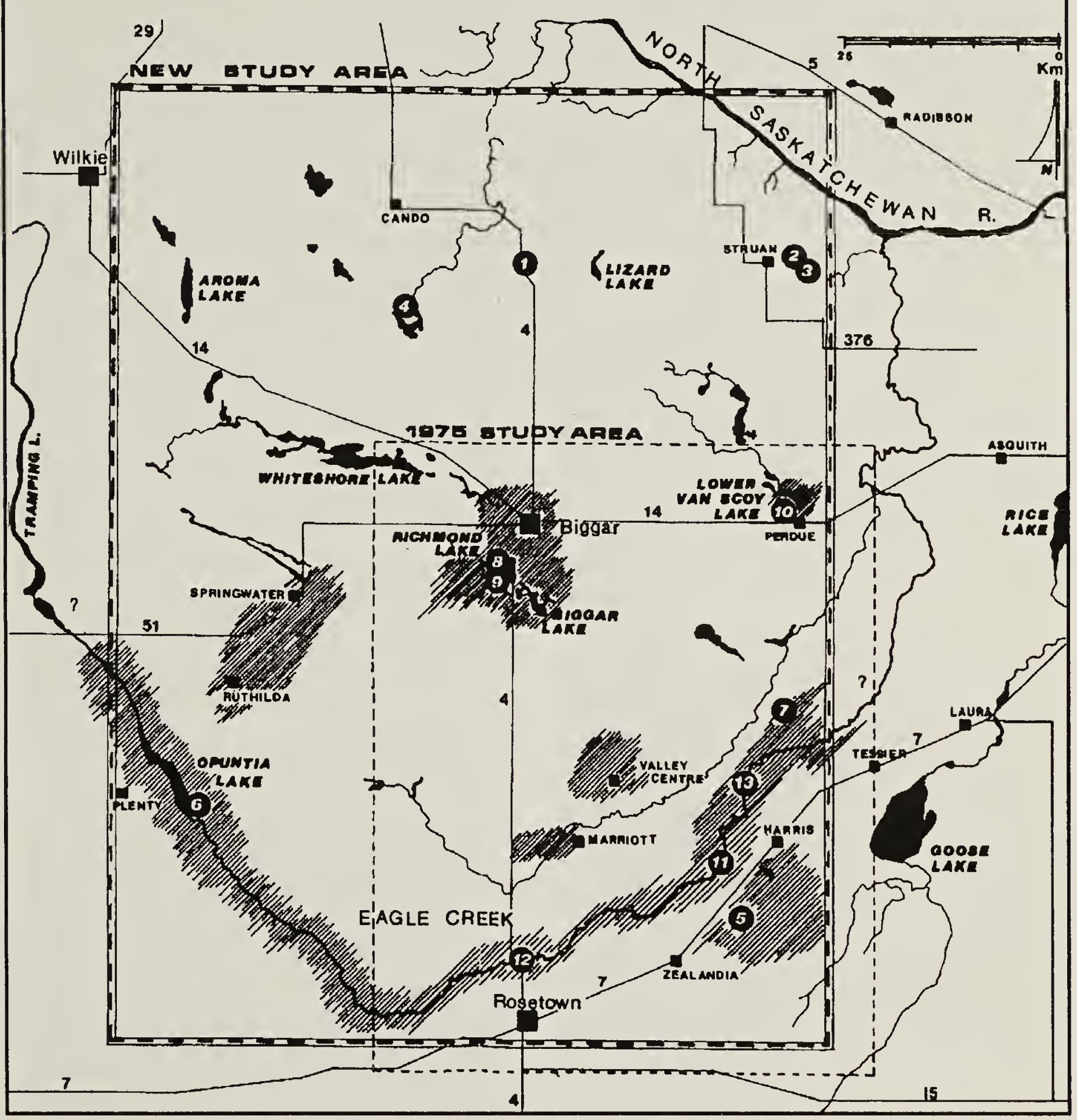

also fortunate to have data from the Biggar Breeding Bird Survey (first conducted by Stan Shadick from 1972 to 1983 , and from 1984 to the present by Guy and Robert Wapple). This survey, spanning 28 years and running west-east through Struan, continues the 'information line' left by the Jaspers.

No Long-billed Curlews were recorded on the Breeding Bird Survey until 6 June 1988 when one was found in pasture near the junction of Highway
4 and Lizard Lake Road (\#1 on Figure 1). No further reports came from the area until June 8,1996 , when two curlews were seen in a pasture $4.8 \mathrm{~km}$ east of Struan (\#2). A second Breeding Bird Survey record occurred on 16 June 1999, when one curlew was seen, in the same pasture east of Struan (\#3). On 16 August 2001 the senior author located Long-billed Curlews near the north end of Kimoff Lake (\#4) further west but at approximately the same latitude as those just described. 
Collectively, these four recent records may indicate that the Long-billed Curlew is experiencing a small resurgence into traditional habitats which were vacated as recently as the 1960 s and 1970 s. However, during several searches of large tracts of prairie, some over 2000 ha in area, north of Perdue, near Aroma Lake, and the extensive pastures abutting the vast alkali flats of Whiteshore Lake, we have failed to find a single curlew!

\section{Within the original study area}

The distribution of the species remains unchanged in the area of the original study and in some areas numbers may be increasing. Longbilled Curlews continue to occupy more or less continuous linear territories along the entire length of Eagle Creek from the upper plateaus adjacent to Opuntia Lake in the west (\#6) to the eastern boundary of the study area north of Harris (an estimated 20-25 pairs). Small numbers continue to nest in the extensive prairies north and west of the former hamlets of Valley Centre and Marriott, as well as south of Biggar southwest to 'Argo Bush', in the Ruthilda-Springwater Lake area (Duane Neufeldt, pers. comm.), southeast of Crystal Beach Lake (just southwest of Harris), and in the Perdue area.

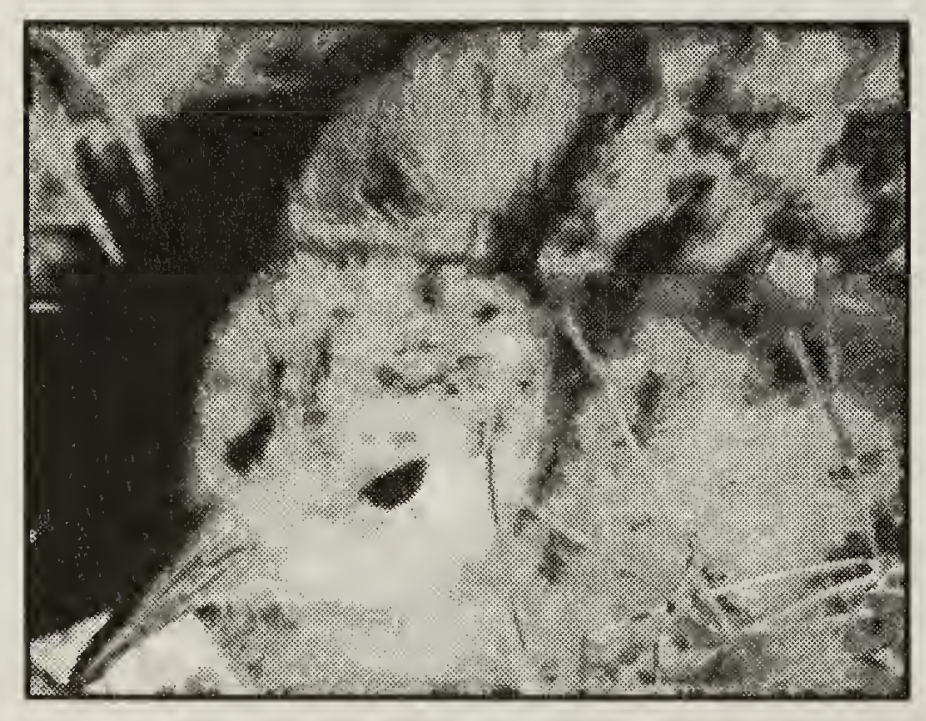

Long-billed Curlew chick

George Tosh
There have been four occasions when groups were encountered, suggesting that, in June, Long-billed Curlews may at times gather in loose feeding flocks of non-breeders, in loose breeding colonies, or a mixture of both. The first occasion was on 18 June 1978 in a large tract of prairie $8 \mathrm{~km}$ southwest of Crystal Beach Lake (\#5), when our discovery of two downy chicks elicited a frantic response from nine adult curlews! The second was on 5 June 1997, when during a survey of the southwest shore of Opuntia Lake, Wayne Harris and Wayne Renaud found six adults, in a loose feeding flock in a wet grassy meadow within 50 metres of the shoreline (\#6). None of the birds was particularly disturbed by the all terrain vehicles being used and were easily approached to within 10 metres without flushing. Our suspicion, at the time, was that these may have been single birds whose mates were incubating eggs or tending broods on the expansive pasture lands adjacent to the lake.

The third and fourth records, and largest numbers to date, occurred on June 9 and 10, 1998. On 9 June, Wayne and Annie Renaud, while driving on a dirt trail $3 \mathrm{~km}$ east and $3 \mathrm{~km}$ south of Feudal (\#7), encountered a group of cattle which startled at their approach and flushed two Long-billed Curlews and two Marbled Godwits. After stopping the truck and assembling the scope, a cursory look further out on to the field revealed several more curlews. After continually flushing the birds, and having them land at various distances from the vehicle, the count totalled at least 22 adult curlews, with the initial two pairs making the most noise, indicating eggs or young were likely present nearby. The curlews were probably attracted to the stubble field to feed on the abundant crop of grasshoppers. This site is located within one kilometre of an 




intermittent creek which drains into Eagle Creek valley.

The following day, 10 June, the authors discovered another group of curlews in a 100 ha pasture $0.5 \mathrm{~km}$ north of the north-west end of Richmond Lake (\#8). Again, while slowly driving along the dirt trail that follows the section line south towards Richmond Lake, we began flushing a mixed flock of curlews, Willets and godwits from the adjacent prairie and stubble fields. For a full hour, we walked a small portion of the area trying to determine an exact count of the curlews. Finally, at dusk, the birds slowly settled into the adjacent pastures, scattering over virtually the entire area of prairie. After scoping the birds silhouetted against the setting sun, the final shorebird count totalled 25 Longbilled Curlews (24 adults and a single newly-hatched chick), 12 Marbled Godwits and 6 Willets. On a short visit the following day, Wayne Renaud and Frank Roy counted 20 adult Long-billed Curlews in the area. Within a week of this find, three more pairs of curlews, all showing territorial behaviour, were found in similarly heavily grazed pasture between 4 and $6 \mathrm{~km}$ south of this location (\#9), making a remarkable total of 31 birds in this cluster. On 25 June, Robert Wapple visited the 10 June site and found 12 adult and two juvenile curlews which had just been startled by a coyote approaching $350 \mathrm{~m}$ distant. Returning to the same area on 7 July, Guy Wapple spent five hours searching and failed to find a single Long-billed Curlew. Given the existence of adjacent pastures and stubble fields, the curlews had possibly dispersed into other areas distant from the original place of concentration.

To the south, in the Elbow area, Frank Roy reported only one large assemblage in June: a total of 50 , (possibly a collection of non-breeders or unsuccessful nesters) on 26 June 1992, in a seeded summer fallow field. ${ }^{4}$

\section{Post-breeding Status}

Reports of post-breeding flocks of Long-billed Curlews in August in 
Saskatchewan are relatively uncommon. ${ }^{3}$ Roy, in the Elbow area, indicated that flocks varying from 5 to 40 have been seen at or near lakes in August; the largest group of 40 was on 15 August 1943 at Luck Lake. ${ }^{4}$ Postbreeding flocks of Long-billed Curlews have been recorded in the RosetownBiggar District on four occasions. On 29 July 1973 , the senior author and Wayne Harris found 5 curlews feeding with a flock of Marbled and Hudsonian Godwits on Lower Van Scoy Lake north of Perdue (\#10). ${ }^{1}$ The largest count of 90 Longbilled Curlews was found feeding in a dry Foxtail Barley (Hordeum jubatum) meadow on the flats of Eagle Creek Valley four $\mathrm{km}$ southwest of Harris on 4 August 1978 (\#11). ${ }^{2}$ On 4 September 1982, Harvey and Annie Renaud recorded a loose flock of 12 feeding on the alkali flats of Eagle Creek north of Rosetown (\#12). At dusk on 11 August 2001, a dispersed flock of 43 Long-billed Curlews was feeding in a Foxtail Barley meadow on the flood plain of Eagle Creek east of Valley Centre (\#13).

\section{Summary}

This paper establishes that the Longbilled Curlew has declined somewhat in numbers since at least 1970 , possibly due to loss of habitat. However, a significant number of Long-billed Curlews continue to breed and gather in post-breeding flocks even here, at the northernmost extremity of their breeding range in Saskatchewan. ${ }^{3}$ Smith suggested that the entire provincial population may number only 3000 adults. ${ }^{5}$ Based on past experience that suggests nesting pairs return to the same territories each year, we speculate that the entire modern population of the Rosetown-Biggar study area numbers approximately 70 to 80 breeding pairs.

\section{Acknowledgements}

We thank Robert Wapple, Wayne Harris and Frank Roy for accompanying us on field trips into the area during which many of these records were made. We wish to acknowledge the valuable legacy of bird records which Ernest and William Jasper collected from 1932 to 1975, and Duane Neufeldt who shared his knowledge of Longbilled Curlews from Duperow-Ruthilda area from 1970 to the present. We also acknowledge Harvey and Annie Renaud who continued to record their observations in the Rosetown-Biggar area from 1975 to 1985 . Sheila Lamont kindly edited an early draft of the manuscript.

1. Harris, W.C. 1974. More Hudsonian Godwits in Saskatchewan. Blue Jay 32(2):101-104.

2. Renaud, W. and D. Renaud. 1975. The Birds of the Rosetown-Biggar District, Saskatchewan. Special Publication No. 22. Saskatchewan Natural History Society. 121 pp.

3. Renaud, W. 1980. The Long-billed Curlew in Saskatchewan: status and distribution. Blue Jay 38 (4):221-237.

4. Roy, F. 1996. Birds of the Elbow. Manley Callin Series, No. 3. Saskatchewan Natural History Society. $325 \mathrm{pp}$.

5. Smith, A. 1996. Atlas of Saskatchewan Birds. Manley Callin Series No. 4 Saskatchewan Natural History Society. 456 pp. 